\title{
Diversity of Native and Exotic Fruit Genetic Resources in Nepal
}

\author{
Ishwori Prasad Gautam and Tek Prasad Gotame
}

Nepal Agricultural Research Council, Horticulture Research Division, Khumaltar, Lalitpur; IPG:

ishworigautam@gmail.com, ORCID: https://orcid.org/0000-0003-0682-9306;TPG@: gotame@gmail.com

Received 24 Nov 2019, Revised 05 Dec 2019, Accepted 14 Feb 2020, Published 17 March 2020

Scientific Editors: Umersh Acharya, Jiban Shrestha, Bal K. Joshi, Manoj Thakur

Copyright $\odot 2020$ NARC. Permits unrestricted use, distribution and reproduction in any medium provided the original work is properly cited.

The authors declare that there is no conflict of interest.

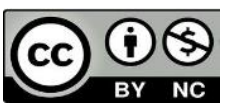

OPEN ACCESS NonCommercial 4.0 International (CC BY-NC 4.0)

\section{ABSTRACT}

Diversity in fruit genetic resources in Nepal is contributed by wild, indigenous and exotic sources. This study was carried out to bring together the available fruit species and cultivars at various stations of Department of Agriculture (DoA), Nepal Agricultural Research Council (NARC), Agriculture and Forest University (AFU) and private farms until the Fiscal Year 2017/2018. Altogather there were 47 species of fruits from tropical zone of Terai (Tarahara, Janakpur, Sarlahi, Parwanipur and Khajura) to cold temperature zone of high hills (Marpha, Rajikot and Satbanj) across the country. Apple diversity was found at Horticulture Research Station, Rajikot, Jumla and has introduced 25 spur type cultivars. National Citrus Research Programme (NCRP), Dhankuta was citrus most diversity areas and has maintained 130 exotic and indigenous germplasms of citrus species followed by NCFD, Kirtipur. Mango diversity was noted at RARS, Tarahara (16 cultivars), RARS, Parwanipur (25 cultivars), Farm of DoA-Sarlahi (30 cultivars), Farms of DoA-Janakpur (18 cultivars), AFU-Rampur (17 cultivars). Some of the private nurseries like Everything Organic Nursery, Patlekhet, Kavre and international organization like Technology Demonstration Centre of ICIMOD, Godawari, Lalitpur were also found to be a diversity centre of many exotic and indigenous germplasms of fruit species. These indigenous fruit genetic resources were also used to develop varieties such as Sunkagati-1 and Sunkagati-2 and Tehrathum Local of acid lime, Khoku Local of mandarin orange, 'Malbhog' of banana which were notified by the National Seed Board, SQCC. The unique fruit genetic resources were 'Pharping Local' (Asian sand pear), 'Sindhuli Junar' (sweet orange), 'Dhankuta Local' and 'Manakamana Local' (mandarin), Local Malbhog (banana), Bhaktapure Lapsi (Nepalese hog plum) etc. which have superior traits than exotic fruits. Unique and wild fruit species were yellow, black and red raspberries (Rubus ellipticus, R. foliolosus and R. acuminatus respectively), bale (Aegle marmelos), pummelo (Citrus grandis), citron (Citrus medica), sweet lime (Citrus limettoides), butter tree or chiuri (Basia buttyacea), tamarind (Tamarindus indica), black plum (Syzygium cumini), wild apple (Mallus baccata), rough lemon (Citrus jambhiri), bayberry (Myrica esculanta), edimayal (Pyrus pashia), black and white ebony (Diospyrus malbarica), wild species of olive (Olea ferruginea and O. glandulifera), wild kiwifruit (Actinidia callosa) etc. Most of the diversity studies were based on phenotypic descriptions. We believe that the number of species and genotypes listed in this article would be increased if detail survey is further carried out. Way forward to utilize these valuable genetic resources has also been discussed in this manuscript.

Keywords: Nepalese fruits, Native fruits, Exotic fruits, fruit diversity

\section{सारांश}

नेपालको फलफल वर्गको आनुवंशिक स्रोतमा विविधता यहाको जंगली, रैथाने, स्थानिय र विदेशी स्रोतहरूले योगदान पुर्याउँछन् । नेपाल सरकारको कृषि विभागका फार्म, नेपाल कृषि अनुसन्धान परिषदका फार्म (नार्क), कृषि तथा वन विश्वविद्यालय र निजी फार्महरूमा उपलब्ध फलफूलका प्रजातिहरूको विबरण अध्यावधिक गर्न आर्थिक वर्ष २०१४ देखि २०१७ मा यो अध्ययन गरिएको थियो। तराई (तराहरा, जनकपुर, सर्लाही, परवानीपुर र खजुरा) को उष्ण प्रदेशिय क्षेत्रदेखि चिसो तापक्रमको क्षेत्र (मार्फा, राजिकोट र सतबाक) सम्म जम्मा ४७ प्रजातिका फलहरू पाइएका थिए । स्याउको विविधता बागवानी अनुसन्धान केन्द्र, राजिकोट, जुम्ला, मार्फा र सतबाकको फार्म थिए भने राष्ट्रय सुन्तला अनुसन्धान 
कार्यक्रम (रा.सु.अ.का.), धनकुटा र एनसीएफडी, कीर्तिपुर अमिलो वर्गका फलफलको सबैभन्दा बढि विविधता भएको फार्म थिए। यी दुवै फार्ममा १३० भन्दा बढि प्रजातीहरु संरक्षण गरिएका छन्। आँपको सवैभन्दा बढि विविधता नार्कको फार्महरु क्षे.कृ.अ. के. तरहरा, क्षे.कृ.अ.क परवानीपुर, सर्लाही फार्म, जनकपुर फार्म, कृषि र वन विश्वविद्यालय, रामपुर छन् । निजी नर्सरी जस्तै सबै जैविक नर्सरी, पात्लेखेत, काभ्रे र इसिमोड, गोदावरी, ललितपुरको टेक्नोलोजी प्रदर्शन केन्द्र जस्ता अन्तर्राष्ट्रिय संस्था पनि विदेशी र स्वदेशी फलफूलको प्रजातिहरूका विविधताका केन्द्र थिए। नेपालका स्वदेशी प्रजातिहरू मध्ये कागतीको सुनकागती १, सुनकागती २ र तेह्रथुम स्थानीय, सुन्तलाको खोकु स्थानीय, केराको मालभोग जस्ता जातहरू विकास गरि राष्ट्रिय बीउबिजन बोर्डले सूचित गरेको छ। एशियाली नासपातीको फपिड्ग स्थानीय, जुनारको सिन्धुली जुनार, सुन्तलाको धनकुटा स्थानीय र मनकामना स्थानीय, केराको स्थानीय मालभोग, भक्तपुरे लप्सी आदि अद्वितीय आनुवंशिक स्रोतहरू भएका फलफूल हुन जसमा विदेशी फलहरू भन्दा उच्च गुणहरू छन्। हामीलाई विश्वास छ कि यदि विस्तृत सर्वेक्षण गर्ने हो भने यस लेखमा सूचीबद्ध प्रजाति र जीनोटाइपहरूको संख्या बढि हुनेछ।

\section{INTRODUCTION}

Nepal is bestowed with diversified climatic conditions with many micro-climatic nitches to cultivate diverse biotypes of fruit species. The complex maze of mountains and ridges, interspersed by deep valleys and low lands are rich in fruit genetic resources (Kaini 1994, Kaini 1999). Among 6,500 species of flowering plants reported by Chalise et al (1993) Nepal is rich in wild edible, exotic and cultivated fruit genetic resources (Joshi et al 2017, Upadhyay and Joshi 2003). The total number of agro-horticultural crops found in Nepal is roughly estimated to be 400 species and subspecies (Regmi 1990). It is believed that Nepal is original home of many fruit species. About 107 indigenous fruit species have been reported in Nepal (Joshi et al 2007). There are 45 species belonging to 37 genera and are reported as wild edible fruits (Kaini 1994). Southern Terai region is suitable for cultivation of true tropical fruits while northern mid-hills and high-hills are suitable for sub-tropical to warm and cold temperate fruit and nut species. In addition, few species of fruits are found growing across agroecological regions. For example, some true tropical fruits such as banana, litchi, pineapple, papaya and mango can be grown in Terai, iner-Terai, foot hills and mid-hills. Similarly, some species of citrus species particularly acid lime can be grown from tropical Terai to mid-hill conditions. From the reviews of the past research initiatives on fruit and nut species, it shows that many exotic fruit germplasm has been introduced in many public farms (Thapa et al 2017, Shrestha et al 2017) but comprehensive documentation of these germplasm is still lacking. In the context of not having explicit database of fruit diversity introduced and maintained in Nepal, this study was carried out to bring together the available indigenous and exotic fruit and nut species in the country so that further research can be streamlined in varietal research and initiate the selection, notification and or release process of promising genotypes. It was also aimed to get insight of the existing and imported fruit germplasm available at the farms of DoA and NARC all over the county.

\section{METHODOLOGY}

This study was carried out by using a standard format of inventory collection of the fruit and nut species available at different farms belonging to DoA, stations of NARC and AFU, Rampur, Chitwan. Information were collected from ARS Pakhribas; NCRP, Dhankuta; RARS, Tarahara, Parwanipur; Lumle and Nepalgunj; HRS, Malepatan and Jumla respectively. Most of the germplasm available and maintained at DoA farms were listed from the web sites of former Fruit Division Directorate (http://fdd.gov.np/index.php/dwndsection). In addition to public farms and stations, field visit and detailed survey was carried out to collect information from Technology Demonstration Centre of ICIMOD and Everything Organic Nursery (EVON), Kavre. Secondary data from previous publications, for example, $\operatorname{HRD}(2014,2015)$ and $\operatorname{NCRP}(2013,2016,2017)$ were also used to update and cross validate the inventory lists. Literature on Conservation and Utilization of Agricultural Plant Genetic Resources in Nepal (CUAPGR) has also been reviewed and updated the findings of Thapa et al (2017), Shrestha et al (2017) and Karki et al (2017).

\section{RESULTS AND DISCUSSION}

\section{Fruit diversity at species and varietal levels}

Citrus fruit diversity: It has been found that National Citrus Research Program, Paripatle (NCRP), Dhankuta and its command areas were the most diversity centre of citrus species (130 species) in 
Nepal (Table 1). NCRP has continued varietal evaluation of sweet orange including 23 exotic and local landraces since establishment. More than 45 different genotypes of citrus (22 mandarin, 14 sweet orange, 5 grapefruit, 3 tangor and 3 tangelo) were introduced from the French National Institute for Agriculture Research (INRA)-CIRAD, France; Japan; Pakistan; and other countries in 2005 and have been preserved and were being evaluated in field gene bank of NCRP, Dhankuta (NCRP 2013).

Table 1. Collection and conservation of citrus germplasm in field gene bank at NCRP, Dhankuta

\begin{tabular}{lll}
\hline Species & No. of germplasms & Source \\
\hline Mandarin Oranges & 32 & France, Japan and Local \\
\hline Sweet Orange & 34 & India and France \\
\hline Tangelo & 3 & France and Japan \\
\hline Tan gore & 4 & France and Japan \\
\hline Acid Lime & 21 & Local \\
\hline Lime & 6 & Local \\
\hline Grape fruit & 8 & France and Vietnam \\
\hline Muntala & 3 & India \\
\hline Rootstocks & 19 & Local and France \\
\hline Total & $\mathbf{1 3 0}$ & \\
\hline
\end{tabular}

Source: NRCP 2017

Among them cv. Washington Navel and Valencia Late of sweet orange has been tested and are pipeline cultivars. Based on the preliminary research finding Washington Navel is recommended for for low altitude, seedless, matures in Kartik-Mangsir (Oct.-Nov.) while Valencia Late is recommended for late season, matures in Chaitra (Mar.-Apr.). National Centre for Fruit Development, Kirtipur is second most diversity centre of citrus species followed by HRS, Malepatan and HRS, Dailekh of NARC (Table 2).

Table 2. Diversity of citrus species at different horticulture farms of Nepal, 2017

\begin{tabular}{|c|c|c|c|c|}
\hline $\mathbf{S N}$ & $\begin{array}{l}\text { English } \\
\text { name }\end{array}$ & Nepali name & Scientific name & Diversity stations (No. of cultivars/genotypes) \\
\hline 1. & $\begin{array}{l}\text { Mandarin } \\
\text { orange }\end{array}$ & Suntala & $\begin{array}{l}\text { Citrus reticulate } \\
\text { L. }\end{array}$ & $\begin{array}{l}\text { DoA, Kirtipur (7), NCRP, Dhankuta (32), ICIMOD, } \\
\text { Godawari (3), HRS, Dailekh (5) }\end{array}$ \\
\hline 2. & $\begin{array}{l}\text { Unshu } \\
\text { mandarin }\end{array}$ & $\begin{array}{l}\text { Unshu } \\
\text { Mandarin }\end{array}$ & $\begin{array}{l}\text { Citrus } \\
\text { unshui }\end{array}$ & NCRP, Dhankuta (5), DoA, Kirtipur (6) \\
\hline 3. & $\begin{array}{l}\text { Sweet } \\
\text { orange }\end{array}$ & $\begin{array}{l}\text { Mausambi / } \\
\text { Junar }\end{array}$ & Citrus sinensis & $\begin{array}{l}\text { NCRP, Paripatle (25), DoA, Kirtipur (11), ICIMOD, } \\
\text { Godawari (7), DoA, Godwari (2) }\end{array}$ \\
\hline 4. & Acid lime & Kagati & $\begin{array}{l}\text { Citrus } \\
\text { aurantifolia }\end{array}$ & $\begin{array}{l}\text { NCRP, Dhankuta (22), HRS, Malepatan (3), RARS, } \\
\text { Nepalgunj (7), DoA, Kirtipur (2), EVON (2), } \\
\text { ICIMOD, Godawari (2), RARS, Parwaipur (1) }\end{array}$ \\
\hline 5. & Pummelo & Bhogate & $\begin{array}{l}\text { Citrus maxima or } \\
\text { grandis }\end{array}$ & DoA, Kirtipur (6), NCRP, Dhankuta (3) \\
\hline 6. & Tangelo & & & NCRP, Dhankuta (6), \\
\hline 7. & $\begin{array}{l}\text { Trifoliate } \\
\text { orange }\end{array}$ & Tinpate & $\begin{array}{l}\text { Poncirus } \\
\text { trifoliata }\end{array}$ & DoA, Kirtipur (3), NCRP, Dhankuta (1) \\
\hline 8. & Hill lemon & Nibuwa & $\begin{array}{l}\text { Citrus } \\
\text { limon }\end{array}$ & $\begin{array}{l}\text { EVON (1), NCRP, Dhankuta (6), DoA, Kirtipur (2), } \\
\text { HRS, Malepatan (1), ICIMOD, Godavari (2) }\end{array}$ \\
\hline 9. & Grapefruit & Sankhatro & $\begin{array}{l}\text { Citrus } \\
\text { paradisi }\end{array}$ & $\begin{array}{l}\text { NCRP, Dhankuta (5), DoA, Kirtipur (1), ICIMOD, } \\
\text { Godawari (1) }\end{array}$ \\
\hline 10. & Kumquat & Muntala & $\begin{array}{l}\text { Fortunella } \\
\text { japonica }\end{array}$ & $\begin{array}{l}\text { DoA, Kirtipur (2), NCRP, Dhnakuta (2), DoA, } \\
\text { Godawari (2), }\end{array}$ \\
\hline 11. & Citrange & & $\begin{array}{l}\text { C. sinensis X P. } \\
\text { trifoliata }\end{array}$ & DoA, Kirtipur (2), NCRP, Dhnakuta (2), \\
\hline 12. & Citron & & $\begin{array}{l}\text { Citrus } \\
\text { medica }\end{array}$ & NCRP, Dhankuta (15), \\
\hline
\end{tabular}

13. Tangor NCRP, Dhankuta (3), DoA, Kirtipur (1)

Figure in paranthesis indicates number of fruit germplasm maintained at different farms. DoA, Department of Agriculture; ARS, Agriculture Research Station; Hort., Horticulture; EVON, Everything Organic Nursery; NCRP, National Citrus Research Program; HRD, Horticulture Research Division; ICIMOD, International Center for Integrated Mountain Development, 


\section{Temperate fruit diversity}

About 10 spur type apple germplasms were collected from RHRS, Mashorbra, Simla and HTS, Kandaghat Solon and 15 germplasms were improted from Canada and planted in 2011 at HRS, Rajikot, Jumla (ARS 2012). The recent result showed that three spur cultivars collected from India, Oregon spur II, Starkrimson Delicious and Red Spur were found to be promising for good fruit quality, storability and disease pest resistant up to now and therefore proposals are being developed for registration by the fiscal year 2019/20. Similarly, some promising fruit germplasm of temperate fruits were imported by Horticulture Research Division, Khumaltar with support of Association Du Bessin Au Nepal, France and Kam For Sud, Switzerland (HRD 2018) (Table 3).

Table 3. Recent introduction of temperate fruit gemplasms

\begin{tabular}{llll}
\hline Species & Varieties/lines & $\begin{array}{l}\text { Year of } \\
\text { introduction }\end{array}$ & Farm/Stations/location \\
\hline Apple Malus & $\mathbf{1 0}$ cultivars collected from India & 2011 & HRS, Jumla
\end{tabular}

pumilla var. Oregon Spur II, Red Chief, Bright N

domestica Early, Red Gold, Vance Delicious, Top

Red, Starkrimson Delicious, Well Spur,

Red Spur, Stark Spur Gold

15 cultivars introduced from Canada

Ambrosia, Blushing Susan, Honey Crisp,

Gala, Red Gravenstein,

Jonagold (P), Jubile Fuji, Pristine,

Redfree, Robinete, Sinta, Sunrise,

Tsagaru, Zestar, Jim

Canada Gris, Baskoop, Malrose, Idared,

Cox Orange, Belchard, Akane, Judaine,

2017

HRS, Jumla and DoA,

Reine des, Reinettes, Boskoop, Florina,

Marpha

Mutterapfel, Prime Red Schneider Apfel,

Sparton, Beuty of Kent, King of Pippin,

\begin{tabular}{llll}
\hline $\begin{array}{l}\text { Apple } \\
\text { rootstocks/ }\end{array}$ & MM111, MM106 & 2017 & HRS, Jumla \\
\hline Walnut & Franquette & 2017 & HRS \\
\hline Hazelnut & Coutard & 2017 & HRS \\
\hline Black Currant & Neva, Andega & 2017 & HRS \\
\hline Himlayan Goji & GT8, 100/130 3L & 2017 & HRS \\
\hline Raspberry & Zeva & 2017 & HRS \\
\hline Peach & Benedite, Surprise & 2017 & HRS \\
\hline Plum & Mirabelle & 2017 & HRS \\
\hline Nectarin & Big Van, Burlat & 2017 & HRS \\
\hline Apricot & Hargrand, Bergeron & 2017 & HRS, Jumla \\
\hline P
\end{tabular}

$\mathrm{P}=$ pollinizer

Source: ARS 2012 and HRD 2018

It has been found that about 15 exotic apple cultivars were introduced at Satbanj and 39 cultivars at Marpha under DoA and 25 cultivars at ARS, Rajikot, Jumla since its establishment. The highest diversity in peach and pear fruits were found at National Central Fruit Development (NCFD), Kirtipur under DoA. More than 40 apple (Malus pumila L.) genotypes were introduced to Nepal, and evaluated for many years at NCFD, Kirtipur before 1985. Clonal rootstocks M9, M26, M27 of Malling series and MM101, MM106, MM111 of Malling Merton series were introduced to a few horticultural stations and were used for propagation in a very limited scale. About 13 exotic cultivars of peach and pear have been maintained at NCFD, Kirtipur. During Horticulture Development Project Phase I and Phase II, Japanese pear ( $P$. pyrifolia) cvs. Shinsui, Shinko, Kosui, Hosui, Chojuro and Okusankichi were introduced. Later, over 40 cultivars of peach (Prunus persica) were introduced in Nepal and grafted on a wild species of peach (Prunus species). At present, National Centre for Fruit Development (NCFD), Kirtipur has maintained 13 European plum cultivars such as Green Gage, Early Transparent Gage, Stanley, Ruth Gestetner and Japanese plum cultivars Santa Rosa, Methley, 
Satsuma, Formosa, Mariposa, Burbank, Kelsey, Oishi Wase and Shiro were also introduced during this period. Similarly, about 13 cultivars of apricot and some popular nectarine cultivars such as Independent, Panamint, Arm King, Ruby Gold, Fantasy, Nectaret-2 and Neyorkert were introduced. Popular persimmon cultivars Fuyu, Jiro, Zenjimoru, Hiratanonashi, Hachiya were introduced from Japan and evaluated since the HDP II. The astringent cv. Hiratanenashi and Aizumisirazu, and nonastringent cv. Matsumoto Wase and Maekawajiro of persimmon were also introduced. Similarly, six exotic chestnut cultivars were introduced to LARC. Sweet cherry is mostly available in private nurseries such as EVON, Kavre and international organization ICIMOD, Godawari.

Clonal rootstocks M9, M26, M27 of Malling series and MM101, MM106, MM111 of Malling Merton series were introduced to a few horticultural stations and were used for propagation of apple in a very limited scale (Devkota 1999). Over 40 cultivars of peach (Prunus persica) were introduced to Nepal, grafted on a wild cultivar of peach (Prunus spp) which is also a rootstock for nectarine (Prunus persica var. nectarina) and almond (Prunus amygdalus) (Schnell 2012).

European pear varieties (P. communis) (Bartlett, Quince, Anjou and Conference) were also introduced at Central Horticulture Centre (CHC), Kirtipur farm and evaluated for cool temperate regions of Nepal. Similarly 44 improved varieties of peach have also been introduced and evaluated and found that Peregrine, Triumph, Elberta, Baby Gold, Sun Crest, Rhodes, Red Haven and Florida Red were high chilling varieties while Orion, Spring Time, French Early, Cardinal, Arm Gold, Florida, Kuratake Wase, Texas, Spring Time, Early Red were low chilling varieties. European plum varieties (Green Gage, Early Transparent Gage, Stanley, Ruth Gestetner) and Japanese plum varieties (Santa Rosa, Methley, Satsuma, Formosa, Mariposa, Burbank, Kelsey, Oishi Wase and Shiro) were also introduced during the period. About 13 varieties of apricot were introduced into Nepal at different times but unfortunately only a few of them have been successful for commercial cultivarion under Nepalese conditions (Devkota 1999). Among those introduced varieties (Blenheim, Titon, Bulida, Rcale Dimola, Prete, Canino, Kaisha, Charmagz, Shakarpara), Shakarpara was found to be the most successful varietiy in Nepal. Popular nectarine varieties such as Independent, Panamint, Arm King, Ruby Gold, Fantasy, Nectaret-2 and Neyorkert were introduced. Popular persimmon varieties Fuyu, Jiro, Zenjimoru, Hiratanonashi, Hachiya were introduced (Devkota 1999).

Similarly, different deciduous fruit varieties were introduced and evaluated at Pakhribas Agriculture Center, Dhankuta (Gautam et al 1995) and Lumle Agricultural Research Center, Lumle (Subedi et al 1995). They further reported the suitability of Anna and Vered, low chilling varieties of apple for the eastern hills.

Table 4. Diversity of exotic and native temperate fruits germplasms in Nepal, 2017

\begin{tabular}{|c|c|c|c|c|}
\hline SN & $\begin{array}{c}\text { English } \\
\text { name }\end{array}$ & Nepali name & Scientific name & Diversity stations (No. of cultivars/genotypes) \\
\hline 1. & Apple & Shyau & $\begin{array}{l}\text { Malus pumila var. } \\
\text { domestica }\end{array}$ & $\begin{array}{l}\text { HRS, Jumla (38), EVON (5), DoA, Daman (17), } \\
\text { DoA, Marpha (39), DoA, Satabanj (18), } \\
\text { ICIMOD, Godawari (9), DoA Godawari (3), } \\
\text { ARS, Pakhribas (2) }\end{array}$ \\
\hline 2. & $\begin{array}{l}\text { Apple } \\
\text { rootstock }\end{array}$ & $\begin{array}{l}\text { Edi } \\
\text { Mayal/Local }\end{array}$ & Pyrus pashia & $\begin{array}{l}\text { DoA, Godawari (8), DoA, Marpha (4), DoA, } \\
\text { Damana (3) }\end{array}$ \\
\hline 3. & Almond & $\begin{array}{l}\text { Kagazi } \\
\text { Badam }\end{array}$ & Prunus amygdalus & $\begin{array}{l}\text { HRS, Jumla (1), DoA, Marpha (1), DoA, } \\
\text { Satbanjh (4), EVON (6), }\end{array}$ \\
\hline 4. & Apricot & Khurpani, & Prunus armeniaca & $\begin{array}{l}\text { ICIMOD, Godavari (7), DoA Daman (1), HRS, } \\
\text { Jumla (3), DoA, Marpha (4), DoA Bonch (3) }\end{array}$ \\
\hline 5. & Blackberry & Kalo Ainselu & Rubus sp. & EVON (5) \\
\hline 6. & Blackcurrent & & Ribes nigrum & EVON (1) \\
\hline 7. & Blueberry & Nilo Ainselu & $\begin{array}{l}\text { Vaccinium } \\
\text { sp. }\end{array}$ & EVON (1) \\
\hline 8. & Gooseberry & & $\begin{array}{l}\text { Ribes } \\
\text { grossularia }\end{array}$ & EVON (2) \\
\hline
\end{tabular}




\begin{tabular}{|c|c|c|c|c|}
\hline $\mathbf{S N}$ & $\begin{array}{c}\text { English } \\
\text { name }\end{array}$ & Nepali name & Scientific name & Diversity stations (No. of cultivars/genotypes) \\
\hline 9. & Chestnut & Katus & $\begin{array}{l}\text { Castanea } \\
\text { mollissima/Castan } \\
\text { ea sp }\end{array}$ & $\begin{array}{l}\text { ICIMOD (2), ARS, Pakhribas (1), HRS, } \\
\text { Malepatan (2), EVON (1), DoA, Kritipur (7), } \\
\text { DoA, Bonch (6), DoA Daman (1), DoA, } \\
\text { Godavari (1) }\end{array}$ \\
\hline 10. & Raspberry & Ainselu & Rubus ideaus & $\operatorname{EVON}(5)$ \\
\hline 11. & $\begin{array}{l}\text { Hazelnut/ } \\
\text { Filbert nut }\end{array}$ & $\begin{array}{l}\text { Khathe } \\
\text { Badam }\end{array}$ & $\begin{array}{l}\text { Corylus } \\
\text { avellana }\end{array}$ & DoA, Bonch (2) \\
\hline 12. & Pear & Naspati & $\begin{array}{l}\text { Pyrus communis } \\
\text { (European) } \\
\text { and P. pyrifolia } \\
\text { (Japanese) }\end{array}$ & $\begin{array}{l}\text { ARS, Pakhribas (3), HRS, Jumla (2), EVON (6), } \\
\text { DoA, Bonch (5), DoA, Daman (6), DoA, Marpha } \\
\text { (3), DoA, Kirtipur (14), ICIMOD, Godawari (11), } \\
\text { HRD, Khumaltar (4), DoA, Godawari (5), RARS, } \\
\text { Lumle, (2) }\end{array}$ \\
\hline 13. & Peach & Aaru & Prunus persica & $\begin{array}{l}\text { ARS, Pakhribas (2), HRS, Jumla (1), EVON (4), } \\
\text { DoA, Bonch (4), DoA, Daman (2), DoA, Marpha } \\
\text { (8), DoA, Kirtipur (14), ICIMOD, Godawari (7), } \\
\text { HRD, Khumaltar (2), DoA, Godawari (9), RARS, } \\
\text { Lumle, (7) }\end{array}$ \\
\hline 14. & Plum & Aarupokhada & Prunus domestica & $\begin{array}{l}\text { ARS, Pakhribas (6), HRS, Jumla (2), EVON (1), } \\
\text { DoA, Bonch (6), DoA, Daman (4), DoA, Marpha } \\
\text { (3), DoA, Kirtipur (5), ICIMOD, Godawari (5), } \\
\text { HRD, Khumaltar (4), DoA, Godawari (5), RARS, } \\
\text { Lumle, (2), DoA, Satbanjh (4) }\end{array}$ \\
\hline 15. & Pecan Nut & $\begin{array}{l}\text { Chuche } \\
\text { Okhar }\end{array}$ & Carya illinoensis & $\begin{array}{l}\text { ARS, Pakhribas (1), EVON (1), DoA, Kirtipur } \\
\text { (4), ICIMOD, Godawari (1), DoA, Godawari(2) }\end{array}$ \\
\hline 16. & Persimmon & Haluwabed & Diospyros kaki & $\begin{array}{l}\text { EVON (1), DoA, Kirtipur (12), ICIMOD, } \\
\text { Godawari (6), DoA, Godawari (2), DoA, Daman } \\
\text { (3), DoA, Satbanjh (4), HRD, Khumaltar (5) }\end{array}$ \\
\hline 17. & Sweet cherry & $\begin{array}{l}\text { Guliyo } \\
\text { Paiyun }\end{array}$ & Prunus avium & $\begin{array}{l}\text { ICIMOD, Godawari (6), EVON (2), DoA, Bonch } \\
\text { (2) }\end{array}$ \\
\hline 18. & Sour cherry & $\begin{array}{l}\text { Amilo } \\
\text { Paiyun }\end{array}$ & Prunus cerasus & EVON (1) \\
\hline 19. & Strawberry & Bhui Kaphal & $\begin{array}{l}\text { Fragaria } \mathrm{x} \\
\text { ananassa }\end{array}$ & EVON (5), ARS, Pakhribas (1) \\
\hline 20. & Walnut & Okhar & Juglan regia & $\begin{array}{l}\text { ICIMOD, Godawari (2), EVON (4), DoA, } \\
\text { Godawari (1), ICIMOD, Godawari (4), DoA, } \\
\text { Bonch (2), DoA, Marpha (2), DoA, Daman (1) }\end{array}$ \\
\hline
\end{tabular}

\section{Diversities in subtropical and tropical fruits species}

Pomegranate: The most diversity area at cultivar level for pomegranate was HRD, Khumaltar. There were 12 germplasms collected from various parts of the country and maintained at the mother stock block of HRD, Khumaltar, Lalitpur. Eight germplasms with accessions, HRDPOM001, HRDPOM002, HRDPOM003, HRDPOM004, HRDPOM005, HRDPOM006, HRDPOM007 and HRDPOM008 were collected in the FY 2013/14 and planted at HRD mother stock block. Two germplasms with accession HRDPOM009 and HRDPOM010 were collected from Manakamana Nursery, Gantaghar, Birgunj, Parsa. Additional two genotypes with accession HRDPOM011 and HRDPOM012 were collected from farmer's field, Milanchowk, Pidhuwa, Tandi, Chitwan in the FY 2014/15 (HRD 2015). These genotypes were multiplied by cuttings and are under multi-location evaluation at four different agro-ecological conditions, RARS, Nepalgunj, ARS, Surkhet, HRS, Dailekh and GRP, Salyan including HRD, Khumaltar. Collected genotypes are maintained at the mother stock block of HRD, Khumaltar, Lalitpur. At the species level, the most diversity area of pomegranate is Dolakha, Nuwakot, Kavre, Sindhuli, Tanahun, Lamjung, Kaski and Palpa. 
Kiwifruit: The first specimens of Actinidia callosa on which the genus is based were collected by Nathaniel Wallich, in Nepal in 1821 (Kaini 1994). Another wild type of kiwifruit is known as thekiphal (A. Callosa var. callosa) primarley available in forest of Solukhumbu district from about 1500 to $2200 \mathrm{~m}$. Other species available in Nepal is A. strigosa, very localized only in Nepal and Sikkim at altitudes of 2500 to $3000 \mathrm{~m}$.

At varietal level, the most diversity area of kiwifruit is a Surya Organic Kiwi Farm located at Phaskot of Patlekhet, Kavre district followed by International Centre for Integrated Mountain Development (ICIMOD), Godawari, Lalitpur. ICIMOD introduced kiwifruit cultivars from India and established a demonstration/production plot at Godawari during 1990s. Some kiwi cultivars namely; Hayward, Bruno, Monte, Allison and Tomori were cultivated in Horticulture farms of Kirtipur and Daman since the year 2000. Red Kiwi, Hayward (both round and oblong), Bruno, Monte, Abbolt, Allisan and ICIMOD Oblong were planted at Surya Kiwifarm, Patlekhet, Kavre in 2005. Similarly, six cultivars Hayward, Monte, Abott, Bruno, Allison and Red Kiwi were planted in 2012 at ARS, Pakhribas, Dhankuta for characterization and evaluation. Horticulture Research Division has planted six kiwifruit germplasms and was under evaluation.

Table 5. Tropical and sub-tropical fruit diversity in in Nepal, 2017

\begin{tabular}{|c|c|c|c|c|}
\hline $\mathbf{S N}$ & English name & Nepali name & Scientific name & No. of cultivars/genotypes \\
\hline 1. & Acid lime & Kagati & $\begin{array}{l}\text { Citrus aurantifolia (Christm.) } \\
\text { Swing }\end{array}$ & 11 \\
\hline 2. & Areca nut & Supari & Areca catechu Linn. & 7 \\
\hline 3. & Avocado & Ghewphal & Persea americana Mill. & 5 \\
\hline 4. & Banana & Kera & Musa paradisiaca Linn. & 20 \\
\hline 5. & Coconut & Nariwal & Cocus nucifera Linn. & 3 \\
\hline 6. & Indian Gooseberry & Amala & $\begin{array}{l}\text { Emblica officinalis Gaerth. Syn. } \\
\text { Phyllanthus emblica Linn. }\end{array}$ & 4 \\
\hline 7. & Grapes & Angoor & Vitis venifera Linn. & 7 \\
\hline 8. & Guava & Amba, Belauti & Psidium guajava Linn. & 11 \\
\hline 9. & Jackfruit & Katahar & Artocarpus heterophyllus Lamk. & 7 \\
\hline 10. & Jujube & Baer & Ziziphus mauritiana Lamk. & 4 \\
\hline 11. & Kumquat & Muntala & $\begin{array}{l}\text { Fortunela japonica (Thunb) } \\
\text { Swing. }\end{array}$ & 2 \\
\hline 12. & Lemon & Nibuwa & Citrus limon (Linn.) Burm. f. & 6 \\
\hline 13. & Litchi & Litchi & Litchi chinensis (Gaertn.) Sonn. & 12 \\
\hline 14. & Macadamia nut & Macadamia nut & $\begin{array}{l}\text { Mecademia integrifolia F. } \\
\text { Muell. }\end{array}$ & 4 \\
\hline 15. & Mandarin orange & Suntala & Citrus reticulata Blanco. & 11 \\
\hline 16. & Mango & Aanp & Mangifera indica Linn. & 30 \\
\hline 17. & Mangosteen & Mangosteen & Garcinia mangostana Linn. & 21 \\
\hline 18. & Papaya & Mewa & Carica papaya Linn. & 19 \\
\hline 19. & Pineapple & Bhuinkatahar & Ananas comosus (Linn.) Merr. & 5 \\
\hline 20. & Sapota & Sapatu & Achras sapota Linn. & 2 \\
\hline 21. & Sweet orange & Junar & Citrus sinensis (Linn.) Osbeck. & 8 \\
\hline 22. & Wood Apple & Bale & Aegle marmelos (Linn.) Corr. & 5 \\
\hline 23. & Trifoliate orange & $\begin{array}{l}\text { Tin Pate } \\
\text { Suntala }\end{array}$ & Poncirus trifoliate Raf. & 5 \\
\hline 24. & Pomegranate & Anar & Punica granatum Linn. & 7 \\
\hline 25. & Kiwifruit & Thekiphal & $\begin{array}{l}\text { Actinidia deliciosa C.F. Liang } \\
\text { \& A.R. Ferguson }\end{array}$ & 8 \\
\hline
\end{tabular}

Source: Gautam and Tiwari 2007; NCRP, 2016; Gotame et al 2014; Kaini 1994

Thirteen accessions of avocado (ARS P A-01, ARS P A-02, ARS P A-03, ARS P A-04, ARSP A-05, ARSP A-06, ARSP A-07, ARSP A-08, ARSP A-09, ARSP A-10, ARSP A-11, ARSP A-12, ARSP A13) were collected from different locations of Dhankuta district and evaluation process is ongoing at ARS, Pakhribas (ARS 2018). The shape and size of fruits have high variations and can be used in new 
variety development. AFU has also maintained Arica nut, mangosteen, guava, avocado, jackfruit, kathe jyamir, chuche okar, and drumstick.

\section{Unique fruit genetic resources in Nepal}

Nepal is rich in wild and indigenous fruit germplasms. Many of the indigenous fruit species are performing as good as or better than exotic varieties. For example, cultivars 'Pharping' (Asian sand pear), 'Junar' (sweet orange), 'Dhankuta Local' (mandarin), 'Kagaji and Sunkagati, Lime' (acid lime) are superior to exotic varieties due to many desirable economic characters. Besides the traditional and exotic varietal crops, there are some fruits which are traditionally or wildly grown in Nepal. For example, Indian gooseberry (Emlica officinalis), yellow, black and red raspberries (Rubus ellipticus, $R$. foliolosus and $R$. acuminatus respectively), pomegranate (Punica granatum), bale (Aegle marmelos), pummelo (Citrus grandis), citron (Citrus medica), sweet lime (Citrus limettoides), butter tree or chiuri (Basia buttyacea), tamarind (Tamarindus indica), black plum (Syzygium cumini), wild apple (Mallus baccata), rough lemon (Citrus jambhiri), bayberry (Myrica esculanta), edimayal (Pyrus pashia), gaub tree (malabar ebony/pale moon ebony (tindu) (Diospyrus malbarica), wild species of olive (Olea ferruginea and O. glandulifera), wild kiwifruit (Actinidia callosa) etc. mulberry (Morus indica), Nepalese hog plum (Choerospondias axillaris), edimayal (Pyrus pashia), common fig (Ficus carica), jackfruits etc. There is ample scope for selection of promising clones from these existing wild relatives through evaluation and selection breeding procedure. Upreti et al (2012) made an inventory of wild edible fruit crops of Nepal from Makawanpur, Tanahun, Dang, Bardia and Kailali districts and recorded 44 wild fruit species. Some of these fruits include Jambol (black jamun), bay berry (kafal), wild gooseberries and figs. Wild relatives of kiwifruit species and its diversity is found in Sankhuwasaba district of Nepal (Kaini 1994, Kaini 1999) and are used as rootstock. Most probably these rootstocks have high abiotic and biotic stress tolerance but have yet to be studied. There are many landraces that associated with certain geography and have potential of geographical indication right (Table 9) (Joshi et al 2017)

Table 9. Nepali geographical indicator (GI) of fruit species in Nepal

\begin{tabular}{|c|c|c|c|c|}
\hline $\begin{array}{l}\text { Commodity/ } \\
\text { Product }\end{array}$ & Land races & Location & $\begin{array}{l}\text { Nepali geographical } \\
\text { indicator }\end{array}$ & Unique traits \\
\hline Apple & Local apple & $\begin{array}{l}\text { Trans-Himalayan } \\
\text { apple of } \\
\text { Marpha/Jumla/Dolpa }\end{array}$ & $\begin{array}{l}\text { Marpha/Jumla/Dolpa } \\
\text { ko Shyau }\end{array}$ & $\begin{array}{l}\text { Very attractive, delicious } \\
\text { and red, high in } \\
\text { anthocyanin content }\end{array}$ \\
\hline Apple & Local apple & $\begin{array}{l}\text { Helambu, } \\
\text { Sindhupalchock }\end{array}$ & Helambu ko Shyau & $\begin{array}{l}\text { Red colour, high } \\
\text { anthocyanin content }\end{array}$ \\
\hline Mayal & Local Mayal & & & \\
\hline Apricot & $\begin{array}{l}\text { Local } \\
\text { Khurpani }\end{array}$ & Humla/Jumla & $\begin{array}{l}\text { Humla ko Chuli (local } \\
\text { apricot) }\end{array}$ & $\begin{array}{l}\text { Oil from seed has } \\
\text { medicinal value }\end{array}$ \\
\hline Banana & $\begin{array}{l}\text { Jhapali } \\
\text { Malbhog }\end{array}$ & $\begin{array}{l}\text { Kawashowti, } \\
\text { Nawalparasi }\end{array}$ & Kawashoti ko Kera & $\begin{array}{l}\text { Scented, tasty, large size, } \\
\text { thin skin and high in flavor } \\
\text { content }\end{array}$ \\
\hline Banana & Ghiu Kera & Lamjung, Tanahun & Local Malbhog Kera & $\begin{array}{l}\text { Scented, small size, thin } \\
\text { skin, testy, high flavor }\end{array}$ \\
\hline Banana & $\begin{array}{l}\text { Mungre } \\
\text { Kera }\end{array}$ & $\begin{array}{l}\text { Gorkha, Lamjung, } \\
\text { Tanahun }\end{array}$ & Mungre Kera & $\begin{array}{l}\text { Extra large size, long } \\
\text { finger, yellow color, thick } \\
\text { skin, cold tolerant }\end{array}$ \\
\hline Guava & $\begin{array}{l}\text { Local } \\
\text { Aamba }\end{array}$ & $\begin{array}{l}\text { Dhunibeshi, } \\
\text { Dhading }\end{array}$ & Dhunibeshi ko Aamba & Delicious, soft \\
\hline Acid lime & $\begin{array}{l}\text { Local Sun } \\
\text { Kagati }\end{array}$ & $\begin{array}{l}\text { Fakchmara, } \\
\text { Terhthum }\end{array}$ & Sthaniya Kagati & $\begin{array}{l}\text { Juicy, yellow and thin skin } \\
\text { colour, small, round size }\end{array}$ \\
\hline Lapsi & $\begin{array}{l}\text { Sthaniya } \\
\text { Lapsi }\end{array}$ & Bhagara, Parbat & Bhagara Sthaniya & $\begin{array}{l}\text { More pulp, tasty, long } \\
\text { storability }\end{array}$ \\
\hline Lapsi & Lapsi & $\begin{array}{l}\text { Lele, } \\
\text { /Lalitpur/Bhaktapur }\end{array}$ & $\begin{array}{l}\text { Bhaktapur ko Lapsi, } \\
\text { Godawari ko Lapsi }\end{array}$ & Sweet and tasty \\
\hline Mandarin & Manakaman & Manakamana, & Manakamana ko & Juicy and tasty \\
\hline
\end{tabular}




\begin{tabular}{|c|c|c|c|c|}
\hline $\begin{array}{l}\text { Commodity/ } \\
\text { Product }\end{array}$ & Land races & Location & $\begin{array}{l}\text { Nepali geographical } \\
\text { indicator }\end{array}$ & Unique traits \\
\hline & a Local & Gorkha & Suntala & \\
\hline Mandarin & $\begin{array}{l}\text { Khoku } \\
\text { Local }\end{array}$ & Khoku, Dhankuta & Dhankuta ko Suntala & Juicy and tasty \\
\hline Mandarin & $\begin{array}{l}\text { Ramjattaar } \\
\text { Local }\end{array}$ & $\begin{array}{l}\text { Ramjattaar, } \\
\text { Okhaldunga }\end{array}$ & Ramjattar ko Suntala & Sweet \\
\hline Mango & $\begin{array}{l}\text { Local } \\
\text { Maldah Aap }\end{array}$ & $\begin{array}{l}\text { Kalyanpur of Siraha } \\
\text { and Mulghat of } \\
\text { Dhankuta }\end{array}$ & $\begin{array}{l}\text { Kalyanpur. Mugaat ko } \\
\text { maaldah }\end{array}$ & $\begin{array}{l}\text { Sweet and attractive } \\
\text { flavour }\end{array}$ \\
\hline Pear & $\begin{array}{l}\text { Pharping } \\
\text { Local }\end{array}$ & $\begin{array}{l}\text { Pharping, } \\
\text { Kathmandu }\end{array}$ & Pharping ko Naspati & $\begin{array}{l}\text { Juicy and delicious, high } \\
\text { fruiting habit, large plant } \\
\text { canopy, large fruits, higher } \\
\text { storability, drought } \\
\text { tolerant plants }\end{array}$ \\
\hline Sweet orange & Junar & Sindhuli & Sindhuli ko Junar & $\begin{array}{l}\text { Sweet, tasty, juicy, fetch } \\
\text { high price }\end{array}$ \\
\hline Sweet orange & Mausam & Dadeldhura & $\begin{array}{l}\text { Dadeldhura ko } \\
\text { Mausam }\end{array}$ & $\begin{array}{l}\text { Juicy, late maturity, can be } \\
\text { harvest until February, } \\
\text { large size, fetch high price }\end{array}$ \\
\hline
\end{tabular}

There were some cultivars of popular fruits selected and commercially cultivated using Nepali gene pool. For example, many types of mandarin grown at present such as Banskhark Local, Parbat Local, Khoku Local; sweet orange cultivar as Junar which is Nepali landraces, have high pomological characters.

\section{Diversity in wild fruit relatives in Nepal}

There are indefinite numbers of wild fruits in Nepal which remain as not studied scientifically thus underutilized fruit germplasm of the country. Ainselu (Rubus ellipticus Sm.), commonly known as the golden Himalayan raspberry or yellow Himalayan raspberry grows in Nepal as well as in China, India, Indo-China region and the Philippines. No research or molecular verification has been carried out to study the origin and distribution of this Asian thorny shrub species. There are unverified reports that roots of Aiselu contain nodules, which fix nitrogen. If this could be confirmed by further study and research, such trait could be widely used to reclaim the marginalized and degraded lands. Similarly, bayberry (Myrica esculanta), Indian gooseberry (Emlica officinalis), butter tree or chiuri (Basia buttyacea), chinkapin (Castanopsis indica), tamarind (Tamarindus indica), black plum (Syzygium cumini), gaub tree (malabar ebony/pale moon ebony (tindu)) (Diospyrus malbarica), mulberry (Morus indica), Nepalese hog plum(Choerospondias axillaris), common fig (Ficus carica), chestnut (Katus) (Castanea indica Roxb.ex Lindl.), and Kyamuna (Cleistocalyx operculatus Roxb.Merr. \& LM Perry) which grow in jungles play a significant role in supplying nutrition, particularly to poor and marginalized people in mid-hills and high-hills. In addition to the ripened fruits, these plants are chief sources of fodder, fire wood, timber and Aurvidic medicine for the local community. Nepalese hog plum (Choerospondias axillaris) and bale (Aeglemarmelos (L.) Correa) are unique to Nepal. Local people of Kathmandu, Bhaktapur and Kavre make candies using Nepalese hog plum fruit which are very popular. Candies and pickles made from tamarind, Nepalese hog plum and Indian gooseberries are popular among the Nepalese people. Commercially grown but in small scale, the bale fruit juice is bottled and marketed as marmelous (the name derived from bale's Latin name, Aegle marmelos) by private companies in Bardia district. People drink bale fruit juice for health benefits (Thapa et al 2018).

Rough lemon (Citrus jambhiri Lush.) is a citrus hybrid from a cross between citron and lemon. Its traits are similar to mandarin orange. Rough lemon is a cold-hardy citrus and can grow into a large tree. There are several cultivars of rough lemon in farmers' fields. Shrubs are often grown as biological fences. They can be grown around national parks andbotanical gardens as ecofriendlyfences. They are also effective to reclaim erosion prone hills to prevent soil erosion. Butter tree (Madhuca butyracea), a native to Nepal and grows mainly in the sub-Himalayan tracts on steep 
slopes, ravines and cliffs at an altitude of 400 to 1400 masl. Chepang (an ethnic community of Nepal) communities process plant fat from butter tree fruit seeds. These trees are mostly grown for production of honey in some districts like Dadeldhura. Another important wild fruit with high potential is chutro (Berberis asiatica), a shrub with many historical uses in Nepal (Komal et al 2011). It has a potential to be promoted internationally due to high qualitywine making fruits.

\section{Utilization of fruit genetic resources in variety development}

With long efforts of research in fruits, two varieties of acid lime Sunkagati-1 and Sunkagati-2 have been released while Khoku Local of mandarin and Tehrathum Local of acid lime have been registered so far. Banana germplasms particularly 'Malbhog', 'Willium Hybrid' and 'G9' were registered by Horticulture Research Division, Khumaltar in the National Seed Board in 2019.

Similarly, collection, characterization and evaluation of new emerging commercial fruits (dragon fruit, avocado, cherry and blueberry) in Nepal have been started since 2018 .

Table 10. Released fruit varieties with yield potential and recommendation domain

\begin{tabular}{|c|c|c|c|c|c|}
\hline $\begin{array}{l}\text { Name of } \\
\text { Fruit }\end{array}$ & Name of variety & $\begin{array}{l}\text { Year of } \\
\text { release }\end{array}$ & $\begin{array}{l}\text { Registered/ } \\
\text { released }\end{array}$ & $\begin{array}{l}\text { Yield potential } \\
\text { (t/ha) }\end{array}$ & $\begin{array}{l}\text { Recommendation } \\
\text { domain }\end{array}$ \\
\hline \multirow[t]{3}{*}{ Acid lime } & Sun Kagati 1 & 2014 & Released & 34.5 & $\begin{array}{l}\text { Terai, inner Terai and Mid } \\
\text { hills }\end{array}$ \\
\hline & Sun Kagati 2 & 2014 & Released & 26.9 & $\begin{array}{l}\text { Terai, inner Terai and Mid } \\
\text { hills }\end{array}$ \\
\hline & Tehrathul Local & 2018 & Registered & & $\begin{array}{l}\text { Terai, inner Terai and Mid } \\
\text { hills }\end{array}$ \\
\hline $\begin{array}{l}\text { Mandarin } \\
\text { orange }\end{array}$ & Khoku Local & 2018 & Registered & $16-24$ & $\begin{array}{l}\text { Terai, inner Terai and Mid } \\
\text { hills }\end{array}$ \\
\hline \multirow[t]{3}{*}{ Banana } & Malbhog & 2019 & Registered & $25-30$ & $\begin{array}{l}\text { Terai, inner Terai and Mid } \\
\text { hills }\end{array}$ \\
\hline & Willium Hybrid & 2019 & Registered & $50-60$ & $\begin{array}{l}\text { Terai, inner Terai and Mid } \\
\text { hills }\end{array}$ \\
\hline & G 9 & 2019 & Registered & $50-60$ & $\begin{array}{l}\text { Terai, inner Terai and Mid } \\
\text { hills }\end{array}$ \\
\hline
\end{tabular}

Source: Gotame et al 2020

\section{Utilization of indligenous fruit genetic resource in Nepali culture}

Indigenous and minor fruits are utilized in several ways in the rural households. Lapsi, Amala, Tamarind are popularly used to prepare pickles and candies. They are preserved for long term storage and used throughout the year. Small quantities of candy and pickles are imported by Nepalese communities abroad. Kafal, Aiselu, Bale, Jamun are eaten or sold fresh as they ripen. Such fruits contribute substantially to the people's diet. Bale fruit is used widely by the Newar community to perform "Bale Bibah" of young girls before menstruation, when they are five to nine years old. Leaves of bale tree are offered to Shiva temples as his favorite leaves. Due to medicinal properties of bale, its juice is becoming popular. People drink bale leaf to cure diabetes. Chiuri fruit is consumed fresh and its seeds are processed to produce ghee, the latter is popular among the Chepang community. Citron and pummelo are used during "Tihar and Chhat" festivals and are also consumed fresh. Apart from them, Newar communities use chestnut (katus), Hade bayer, Satibayer, persimmon, walnuts during the Tihar festival. While, in Brahman-Chetri communities, walnut is crushed at the door during "Bhaitika" by sisters to symbolically smash the enemies of their brothers. Due to nutritional value and beneficial health effects, the demands for different types of nuts are increasing (Thapa et al 2018).

\section{WAY FORWARD}

Fruit germplasms are scattered across the country. All the fruit germplasms are being maintained in field. Therefore, a National Gentic Resource Centre including fruit germplasm repository should be established to utilize these introduced and exiting species in fruit development. Along with 
germplasm repository, there should be a provision of freeze preservation and cryopreservation, invitro as well as a field gene banks. These fruit germplasms available in public organization and private farms should be characterized, evaluated, multiplied and selected for wider geographical recommendation based on yield performance, export quality and market nitch from the single door.

\section{CONCLUSION}

The fruit diversity showed that Nepal is rich in both exotic and native fruit genetic resources, but research in fruit varietal evaluation has not been streamlined. Hence streamlining of fruit research in public sector is a pressing need of time. There are a number of remote and hard-to access areas within Nepal that have yet to be explored for potentially valuable indigenous fruit species for commercial purposes.

\section{ACKNOWLEDGMENT}

The authors acknowledge the horticulture farms of RARS, HRS and ARS (NARC) and horticulture farms under DoA for providing the valuable information of their stations. Thanks to EVON, Kavre and ICIMOD for providing the information to update native and exotic fruit diversities.

\section{REFERENCES}

ARS. 2012. Annual Report - 2068/2069 (2011/2012). Agriculture Research Station, Rajikot, Jumla.

Chalise SR. 1993. Natural Resource Management in Mountain Environment. ICIMOD, Kathmandu, Nepal.

Devkota LN. 1999. Deciduous fruit production in Nepal. 13 May 2011. http://www.fao.org/ docrep/004/ab985e/ab985e09.htm, http://www.fao.org/docrep/004/ab985e/ab985e09.htm.

Gautam DM and S Tiwari. 2007. Commerical Banana Cultivation. Institute of Agriculture and Animal Science, Paklihawa Campus, Bhairahawa (Booklet in Nepali language).

Gotame TP, KP Paudyal and PP Khatiwada. 2014. Status of Fruit and Nut Genetic Resources in Nepal, Indigenous and Exotic Varietal Inventory. Horticulture Research Division, Nepal Agricultural Research Council, Khumaltar, Lalitpur. NARC Publication Serial No. 0090-12 (2013/14).

Gotame TP, IP Gautam, SL Shrestha, J Shrestha and BK Joshi. 2020. Advances in fruit breeding in Nepal. Journal of Agriculture and Natural Resources, 3(1): 301-319. DOI: https://doi.org/10.3126/janr.v3i1.27183

HRD. 2014. Annual Report 2070/71 (2013/14). Horticulture Research Division, NARC, Lalitpur, Nepal.

HRD. 2015. Annual Report 2071/72 (2014/15). Horticulture Research Division, NARC, Lalitpur, Nepal.

HRD. 2018. Report on the National Horticulture Working Group Meeting, $30^{\text {th }}$ Kartik, $2075\left(16^{\text {th }}\right.$ November 2018). Horticulture Research Division, NARC, Khumaltar, Lalitpur, Nepal.

Joshi, N, K Kehlenbeck and BL Maass. 2007. Traditional neglected vegetables of Nepal: Their sustainable utilization. Economical Botany, 24: 241-278.

Joshi BK, AK Acharya, D Gauchan, D Singh, KH Ghimire and BR Sthapit. 2017. Geographical indication: A tool for supporting on-farm conservation of crop landraces and for rural development. In: Conservation and Utilization of Agricultural Plant Genetic Resources in Nepal (BK Joshi, HB KC and AK Acharya, eds). Proceedings of 2nd National Workshop, 22-23 May 2017, Dhulikhel; NAGRC, FDD, DoA and MoAD; Kathmandu, Nepal; pp.50-62. http://moad.gov.np/public/uploads/855517450Plant\%20Genetic\%20Resources_CUAPGR_Nepal-min.pdf

Joshi BK, HB KC and AK Acharya, eds. 2017. Conservation and Utilization of Agricultural Plant Genetic Resources in Nepal. Proceedings of 2nd National Workshop, 22-23 May 2017, Dhulikhel; NAGRC, FDD, DoA and MoAD; Kathmandu, Nepal. http://moad.gov.np/public/uploads/855517450Plant\%20Genetic\%20Resources_CUAPGR_Nepal-min.pdf

Joshi K and R Joshi. 2011. Indigenous knowledge and uses of medicinal plants in Macchegaun, Nepal. IJTK. 10: $281-286$.

Joshi N, K Kehlenbeck and BL Maass. 2007. Traditional neglected vegetables of Nepal: Their sustainable utilization. Economical Botany, 24: 241-278.

Kaini BR. 1994. Status of fruit plant genetic resources in Nepal. In: Upadhya, M. P, H. K. Saiju, B. K. Baniya and M. S. Bista (Eds). Plant Genetic Resources, Nepalese Perspectives. Proceeding of the national workshop on plant genetic resource conservation, use and management organized by NARC at Kathmandu 28 Nov-1 Dec, 1994. NARC and IPGRI. pp. 103.

Kaini BR. 1999. The wild relatives of fruit crops in Nepal. National Conference on Wild Relatives of Cultivated Plants in Nepal, organized by Green Energy Mission/Nepal on June 2-4, 1999. Kathmandu, Nepal.

Karki S, G Rizal, R Manandhar, PN Atreya and TP Gotame. 2017. Minor fruits in Nepal: utilization and conservation efforts. In: Conservation and Utilization of Agricultural Plant Genetic Resources in Nepal. 
Proceedings of $2^{\text {nd }}$ National Workshop May 22-23, 2017, Dhulikhel. Nepal Agricultural Research Council/Ministry of Agricultural Development, Kathmandu, Nepal; pp.143.

Komal, S, B Ranjan, C Neelam, S Birendra and SN Kumar. 2011. Berberis aristata: A Review. International Journal of Research in Ayurveda \& Pharmacy 2(2):383-388.

NCRP. 2013. Annual Report 2069/70 (2012/13). National Citrus Research Programme, Paripatle, Dhankuta.

NCRP. 2014. Annual Report 2070/71 (2013/14). National Citrus Research Programme, Paripatle, Dhankuta.

NCRP. 2015. Annual Report 2071/72 (2014/15). National Citrus Research Programme, Paripatle, Dhankuta.

NCRP. 2016. Annual Report 2072/73 (2015/16). National Citrus Research Programme, Paripatle, Dhankuta.

Pradhan SBN, PP Shrestha and PK Thapa. 2016. Horticulture in Nepal; Journey in the last six decades. In: Six decades of horticulture development in Nepal. Nepal Horticulture Society, Lalitpur, Nepal.

Regmi PP. 1990. Underexploited crops in Nepal, Agri.News, Year 1, Vol 9.

Schnell MA. 2012. The Future Potential of Horticultural Plant Discovery, Improvement, and Production in Nepal. HortScience 47 (7): 828-830.

Shrestha GP, DM Gautam, CR Gurung, GD Subedi, K Poudel and A.K Acharya. 2017. Diversity and Prospect of Temperate Fruit Crop Development in Nepal. In: Conservation and Utilization of Agricultural Plant Genetic Resources in Nepal. Proceedings of $2^{\text {nd }}$ National Workshop May 22-23, 2017, Dhulikhel. Nepal. Nepal Agricultural Research Council/Ministry of Agricultural Development, Kathmandu, Nepal. pp.308

Subedi PP, DP Lohar and GB Gurung. 1995. Fruit crop technologies developed by Lumle Agricultural Research Centre. Seminar paper presented for the horticulture seminar to be held at Fruit Development Project, Kirtipur, Kathmandu from 22-24 February 1995. Department of Agriculture Development, Harihar Bhawan, Lalitpur, Nepal.

Thapa M, TP Gotame and S Dhimal. 2018. Minor and Underutilized Fruit Diversities in Nepal: Strategies for Conservation and Utilization for Livelihood Improvement for Small holder Farmers. A paper presented in the International workshop on 'Wild Harvests, Governance and Livelihoods in Asia (WHGLA)", Nov.30 to Dec. 2, 2017, Kathmandu, Nepal.

Thapa MB, U Acharya, S Dhimal, B Sthapit, PP Khatiwada and TP Gotame. 2017. Diversity and Utilization Status of Tropical and Sub-tropical Fruit Genetic Resources in Nepal. Conservation and Utilization of Agricultural Plant Genetic Resources in Nepal. Proceedings of $2^{\text {nd }}$ National Workshop, 22-23 May 2017, Dhulikhel, Nepal. Nepal Agricultural Research Council, Nepal, 302-304.

Upadhyay MP and BK Joshi. 2003. Plant Genetic Resources in SAARC Countries: Their Conservation and Management: Nepal Chapter. SAARC Agriculture Information Center; pp. 297-422. http://www.elibrary.icrisat.org/SATELib_files/SATELibNewsV4I3Mar2007.htm\#NAB

Upreti Y, RC Paudel, KK Shrestha, S Rajbhandary, NN Shrestha, UB Tiwari and H Asselen. 2012. Diversity of Use and Local Knowledge of Wild Edible Plant Resources in Nepal. Journal of Ethnobiology and Ethnomedicine 8: 115.

||------||-------|| 